\title{
LANDSCAPES AND THROUGHSCAPES IN ITALIAN FOREST WORLDS: Thinking Dramatically about the Anthropocene
}

\author{
ANDREW S. MATHEWS \\ University of California, Santa Cruz \\ (iD) http: / / orcid.org/0000-0002-6350-7533
}

The pine and chestnut forests of the Monti Pisani, only five kilometers south of Lucca in central Italy, feel very far from the tourist sights of the city center and from the industrial sprawl of paper, furniture, and shoe factories that spreads across the plain. As in many Mediterranean places, mountains and valleys are near each other, but in many ways they constitute different worlds (Braudel 19721973). These are certainly not the landscapes that most people think of when I tell them I am working in northern Tuscany. The few human visitors are mushroom pickers, hunters, the occasional mountain biker, sometimes volunteer firefighters or road maintenance crews. Although these forests are often empty of people, they are empty in a particular way; evidence of former human use is omnipresent. This is a place where people, trees, and other nonhumans have been entangled for a very long time. Traces of these past relationships are visible in the forms of trees, areas of forest, banks, terrace walls, and drainage systems. Through my practices of walking, looking, and wondering, I have been tracing the ghostly forms that have emerged from past encounters between people, plants, animals, and soils. From such practices of wondering, I have learned to tell stories about landscape change, which, I argue, suggest a way of engaging with the politics of global environmental change.

CULTURAL ANTHROPOLOGY, Vol. 33, Issue 3, pp. 386-414, ISSN 0886-7356, online ISSN 1548-1360. (C) American Anthropological Association 2018. Cultural Anthropology journal content published since 2014 is freely available to download, save, reproduce, and transmit for noncommercial, scholarly, and educational purposes. Reproduction and transmission of journal content for the above purposes should credit the author and original source. Use, reproduction, or distribution of journal content for commercial purposes requires additional permissions from the American Anthropological Association; please contact permissions@americananthro.org.DOI:10.14506/ca33.3.05 
These anthropogenic forest histories inspire contemporary environmental politics. The material traces of firewood cutting, tree cultivation, pastoralism, and plant disease are temporal rhythms that inspire projects of tree care or biomass energy production. Each of these projects responds to a different sense of what these forests are, of where they might be going, and of how to act in the face of global environmental change. This multiplicity of pasts and futures can help us to make political sense of the Anthropocene, the contemporary era when almost all ecosystems around the world have been in some measure affected by human activities. ${ }^{1}$ Critics of climate-change policy (Hulme 2012), and more recently of the concept of the Anthropocene (Moore 2015), have criticized depoliticized scientific accounts of global environmental change that focus on a single account of the world that is supposed to inspire political action to protect the environment. Rather than recounting a single history that produced a unified landscape, in what follows I describe overlapping and interwoven throughscapes linked to multiple histories. From these storylines a different account of Anthropocene politics can emerge.

The first history I recount centers around the impact of international trade, which moved pathogens around the world and destroyed chestnut cultivation in this area between the mid-nineteenth and mid-twentieth centuries. In this account, the storyline is linked to international trade, to the unintentional journeys of water-mold spores, and to the capacities of chestnut trees to develop new forms of symbiosis that halt the advance of some pathogens. The second history starts in the early nineteenth century, and it tells the tale of capitalism and industrialization. Peasants and shepherds who were transformed into industrial and service workers emerge as key actors in this account. ${ }^{2}$ Changing forms of agriculture and the gradual transformation of urban metabolisms caused fire-dependent pine trees to spread across these mountains when litter raking, pastoralism, and anthropogenic burning were eliminated. In the present moment, farmers, foresters, and others draw on these histories of transformation and cultivation as they imagine how they might transform parts of the landscape to bring into being different environmental futures. These landscapes are simultaneously concrete and material, historical and imaginative. They are linked to multiple histories and rhythms that can help us escape from thinking of nature or history as singular (what John Law [2015] calls a “one-world world”). Multiplying our understandings of possible pasts and futures, and of who might be helped or hurt by these futures, makes the Anthropocene political. 


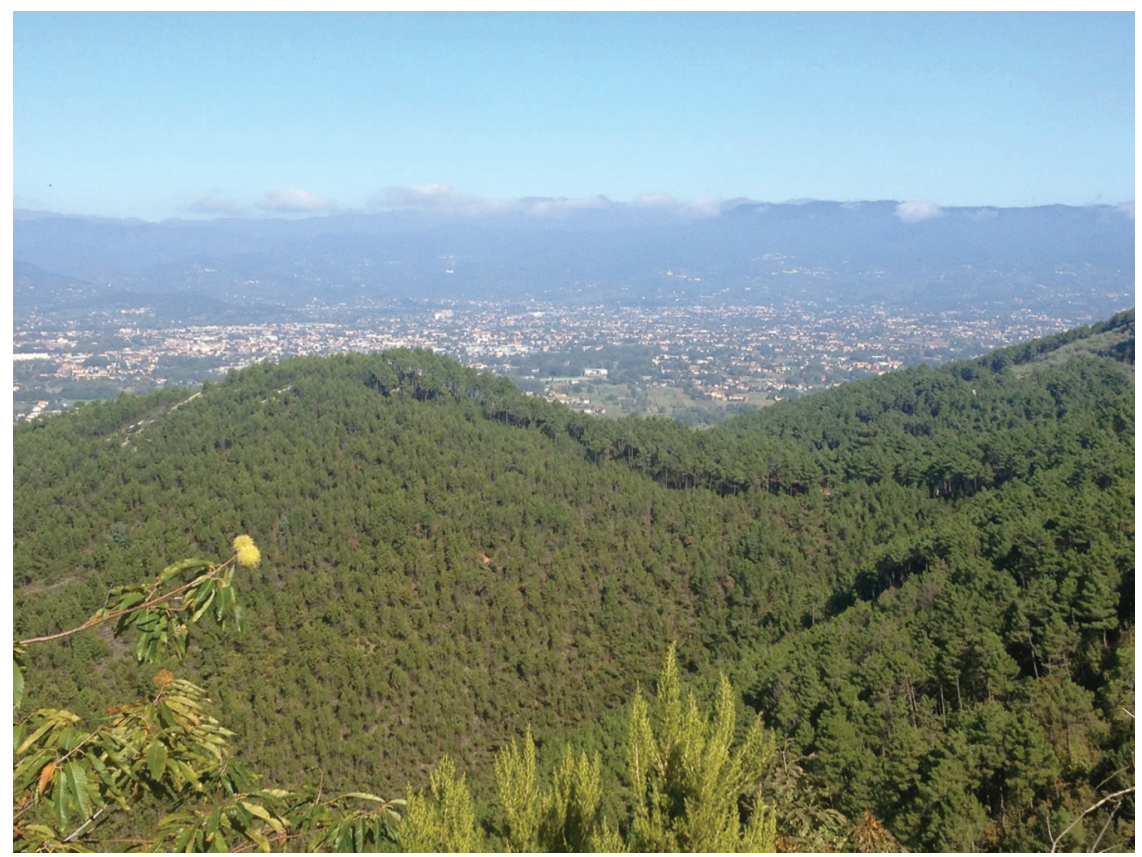

Figure 1. Monti Pisani, with Lucca in the background. Photo by Andrew S. Mathews.

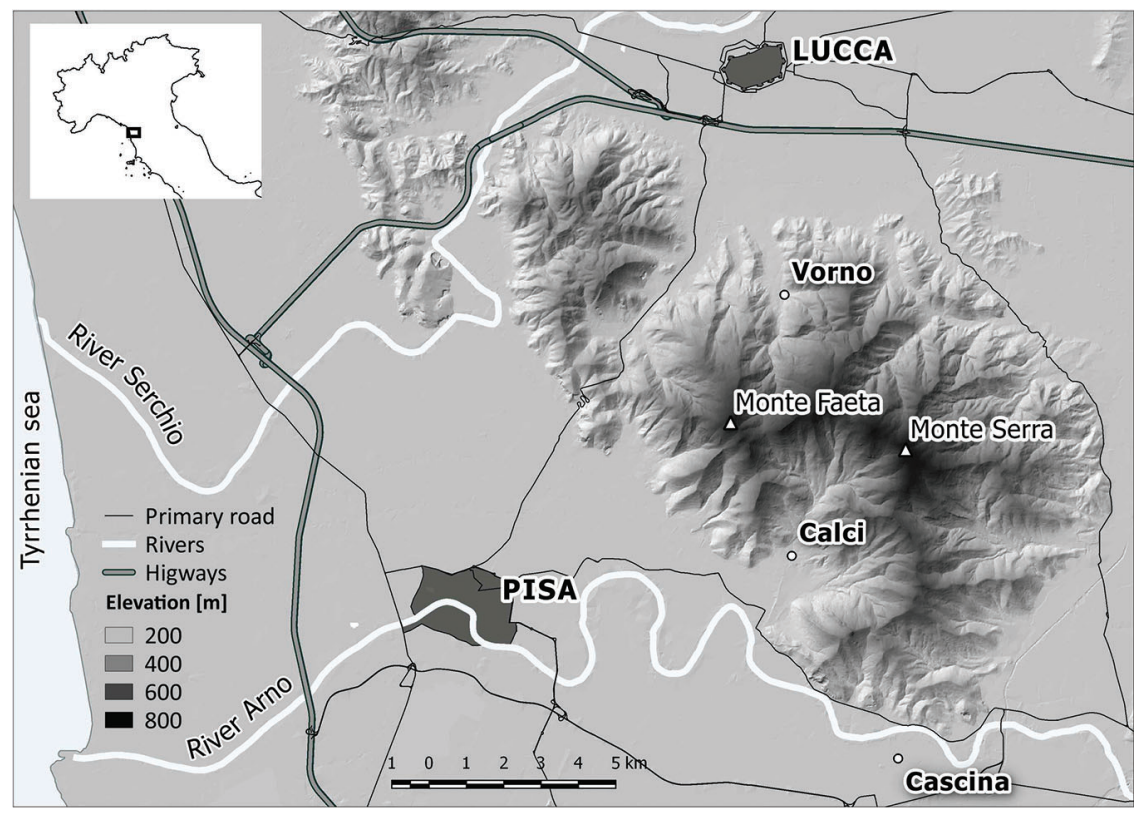

Figure 2. Map of the area around Monti Pisani. Map by Fabio Malfatti, using data from the Regione Toscana. 
The example of the Monti Pisani shows how we can learn to notice multiple coexisting Anthropocenes through the mundane practices of walking, looking, and wondering at strange ontologies, ${ }^{3}$ of archival research, oral history, and drawing. These practices are suitable not only for forests, but for thinking through material politics in other parts of the world, from urban parks to river deltas and sewage systems.

\section{LANDSCAPE FACTS, HISTORIES, AND ONTOLOGIES}

Landscape is a deeply ambiguous term with a rich history. Many scholars see landscape as an ideological construct, a canonical standard of elite taste that might support capitalism or state control (Berger 1973; Cosgrove 1985). More recently, Kenneth Olwig $(1996,630)$ has reclaimed a substantive understanding of landscape as "a place of human habitation and environmental interaction" with particular legal, cultural, and economic histories. As Anna Tsing (2015) points out in The Mushroom at the End of the World, landscapes emerge through encounters between people and other beings, including soils, mushrooms, and disease organisms. In what follows I describe the kinds of landscapes and histories that emerge from encounters between people, trees, soils, and terraces in formerly cultivated landscapes in central Italy. Perhaps most important, this kind of landscape description pushes us to think about how particular forms emerge through encounters. Ontologies are transformed through partial relations between these beings, and the forms of plants and terraces offer clues to the biographies of particular organisms.

At a larger scale, landforms such as terraces and drainage systems tell us histories of human labor and attention to plants, soils, and weather. Encounters both with individual organisms and with landscapes press us to explore or rediscover research methods of drawing and natural history. These methods prove well suited both to the open-ended nature of these encounters and to tracing the forms that result from encounters between people and nonhumans (people, sheep, trees), and between nonhumans and other nonhumans (trees, soils, disease, fire). Such an ethnography of the landscape requires attention to the temporal rhythms of processes as different as rapidly moving fires and slow-growing trees, soil formation, daily cycles of weather, and the structural violence of politico-economic transformation and state formation.

Knowledge of the landscape, with its attention to multiplicity and scalar instability, behaves differently from the kinds of knowledge explored by much scholarship in the anthropology of science and in science and technology studies 
(STS). Within STS, canonical work has concerned itself with how particular facts become stabilized and come to be accepted, such as the scallop reproduction described by Michel Callon (1986) or the pasteurization practices examined by Bruno Latour (1988). Such approaches emerge from studies of laboratory practice, and they often describe how a single fact or version of the world is either accepted or rejected in particular locations and before particular audiences. More recent work has pointed to multiple enactments that emerge through practices linking multiple sites (Mol 2002). Knowledge of landscapes more closely resembles this way of thinking. In particular, thinking with enactments suggests a kind of surprise, given the indeterminacy and slipperiness of what is enacted (Law and Lien 2013). These qualities, as they arise from particular encounters with trees and terraces, form part of what produces the multiple coexisting and somewhat unstable histories and knowledges of landscape that I describe in this essay.

Knowledge of landscapes contains indeterminacy, texture, and a possibility of scale change quite alien to the kinds of facts with which STS and anthropology have mostly concerned themselves. Such knowledge contains indeterminacy and fields of unresolved texture, smaller details that can become significant and change our understanding of what we take to be larger scales (or vice versa). ${ }^{4}$ This is not just a feature of the landscapes that we ordinarily think of. Come close to a tree and you will see entire landscapes of relations at every scale, from the pattern of bark that tells you of an ancient tree to the tiny red fungi that show a tree to be infested by chestnut cancer (farmers notice these spores with fear) or the dry crackled callous that shows that the cancer has itself been infested by a virus that prevents it from killing the tree (chestnut farmers wait breathlessly for such signs of disease stabilization). Come close to look at such details and your understanding of whether an area of forest landscape is doomed or healthy can radically change. The relations between details and large-scale patterns are always provisional: our changing understanding of a particular detail can change our perception at another scale entirely. I arrived at this kind of knowledge of landscape by moving back and forth between intimate encounters with details of tree form and landscape pattern, between interviews with farmers and visits to archives. As I moved back and forth, I gradually came to foreground two histories in accounting for some of the details, stories, and landscape patterns that had come to be significant for me. In this account of how I came to know about a landscape, I do not only draw on interviews or archival records. My own practices of noticing more-than-human relations of people, plants, and soils form part of the back-and-forth movement 
through which I came to settle, provisionally, on the histories and perceptions of landscape that I recount in this essay.

Within the STS tradition, the flourishing scholarship on infrastructure most closely resembles this way of thinking. ${ }^{5}$ Like landscape, infrastructure engages with distributed patterns of material structures and the multiple local practices that sustain them. Infrastructures can be (and usually are) multiple, they can lie through each other, and they can be sustained by multiple communities of use, as in Jessica Barnes's (2014) account of drainage and irrigation infrastructure in Egypt or Ashley Carse's (2014) account of road and canal infrastructures in Panama. There are important resonances between a more phenomenological approach to infrastructure (see Chu 2014) and my own approach to landscape ethnography.

In the forests where I work in Italy, the capacities of particular chestnut trees to resist disease or to be grafted to produce fruit have given rise to tended trees, to linguistic classifications of these trees, and to an apparatus of law and property that protects the landscapes on which these trees live. Linguistic terms, practices of care, and the morphologies of trees constitute a dense empirical field. Words that describe enactments do not fully capture the material and imaginative surprises of the world and remain in a perpetually unstable relationship to what they denote. Strange ontologies are present in the mundane and the everyday, from my meetings with shape-changing chestnut trees to my wondering whether a tree stump I encountered was dead or alive to my experience of looking up to notice the landscape pattern of flowering chestnut across a mountaintop. Carla Hustak and Natasha Myers's $(2012$, 97) formulation of involutionary momentum draws attention to the processes through which I became involved with plants, trees, and terraces, to the "affective push and pull among bodies, including the affinities, ruptures, enmeshments and repulsions among organisms constantly inventing new ways to live with and alongside each other." Trees, diseases, and terraces are relational ontologies (see Barad 2003) that compelled my attention and made me hesitate in disconcertment as I encountered beings that I can only partially describe. One method that is particularly suited to this experience of noticing the coming into being of perceptions through particular encounters is the use of drawings. A line gestures toward what mattered in a particular moment of perception when I noticed a partial relationship, and it explicitly relegates to the background what was not noticed or was not relevant to that encounter.

In this practice of landscape ethnography, every perception is at once speculative, partial, and resolutely empirical. Noticing landscape features, trees, or soils takes a double form of wondering (what is this thing that I am in relation with?) 
and wonder at the mysteriousness and indeterminacy of the world, where our descriptions are always provisional and partial. Tim Ingold $(2011,2012)$ has long argued that material forms emerge from ecological relations in a world of process. I would add that the unending emergence of forms of language and noticing constitute an important empirical fact about what it feels like to be human in a world of process, where descriptions are never enough and where more words might come to be needed to sharpen our capacity to notice and describe. My own changing sensorium provided data for this essay, as did the fact that my perceptions are persistent, embodied, and yet unstable. Just as the descriptions of a particular organism are partial and tentative, so too are landscape descriptions partial and tentative and inhabited by many details not relevant at that level of perception. It is through a principled tacking back and forth between details and patterns that I learned to perceive new patterns and histories.

In a classic article, the feminist geographer Diane Rocheleau (1995) draws on Donna Haraway's concept of situated knowledges to argue for the use of multiple methods in political ecology. I suggest that we can expand on this insight to think of our current task as one of linking coexisting processes, histories, and ontological transformations that emerge through relations among beings. Drawing on multiple lines of evidence and attending to details of plant and terrace form has allowed me to notice multiple histories and landscape patterns. These patterns are throughscapes, perceptible landscape patterns that exist in partial relation to each other and that overlap with each other but have different histories, organizations, and temporalities and are always unstable in relation to the details and textures that they only partially contain. As my colleague Anna Tsing pointed out to me on a forest walk, what I am calling throughscapes are also different ontologies partially linked to each other. Throughscapes are intensely real, but they are also complex time machines. ${ }^{6}$ These are space-time patternings that I learned to notice through my work of linking sensory curiosity to archive and map, of linking drawings and photographs with field notes from walks and conversations with farmers, biologists, and others.

\section{READING GHOSTLY PRESENCES IN FORESTS}

Walking through the forests of the Monti Pisani with my botanist assistant Francesco Roma-Marzio, I note what tree, shrub, and understory plant species we see and what forms they have, jotting these down as sketches in my notebook, making notes of impressions and speculations. As a botanist, Francesco names understory plants for me, and the two of us provoke each other with stories of 
human use of landscapes. Drawing on my training as a forester, I tell him how the shapes of trees and shrubs tell me stories of tree cutting and regrowth, of fire and grazing. Echoes of conflicts over property and landscape are present in tree form. Remnant ancient cultivated castagneti (chestnut orchards) tell us of centuries-long relationships with peasant agriculturalists who formerly sculpted chestnut, oak, and pine trees into the particular forms that produced food, timber, fodder, and fuel, while also providing pasture for sheep and goats (Puccinelli 2010; Giannini and Gabbrielli 2013; Squatriti 2013). Notebooks, interviews, photographs, and sketches contain something of my phenomenological experience of encounters with shape-changing ancient trees and terrace systems. Perhaps a stump is truly dead, but it may also resprout and come alive. The image below shows the first really large cultivated chestnut that Francesco and I encountered. Note the polloni (suckers) sprouting from the base of the tree. We guessed that the size of the polloni told us that they had been cut back five to eight years ago, but based on later experience, I would guess more like two or three years.

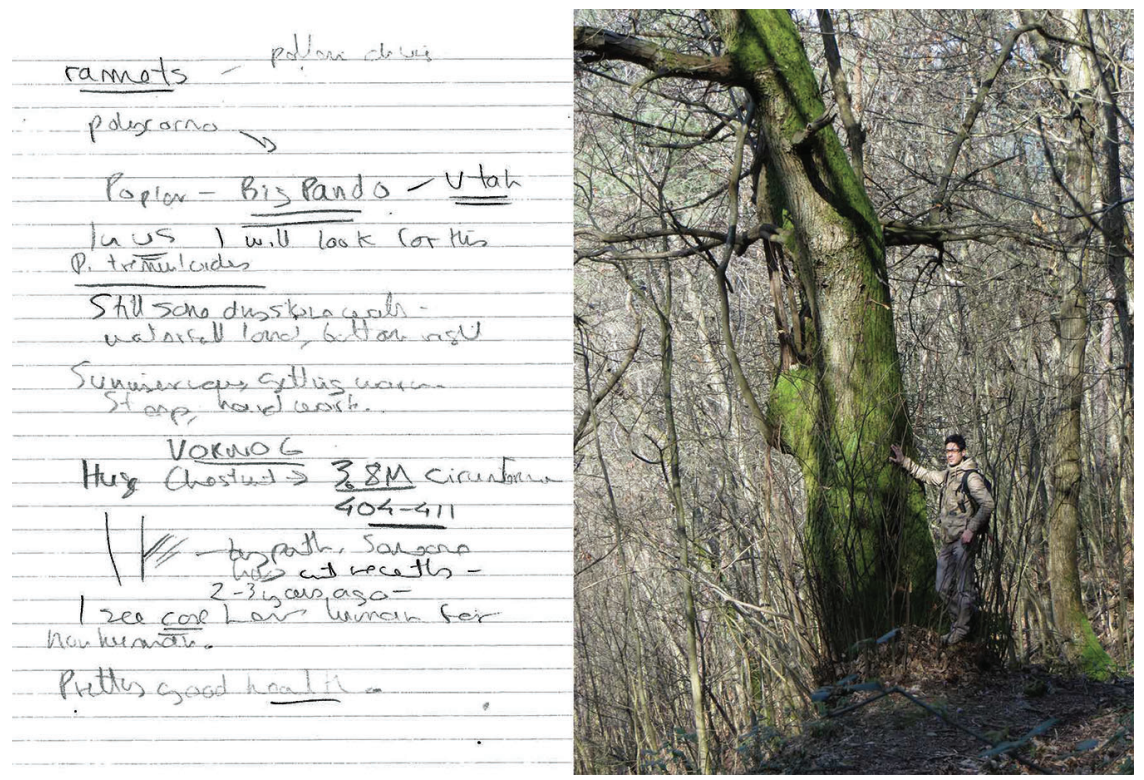

Figure 3. Page from the author's field notebook, with a sketch of an ancient chestnut tree, paired with a photo of the tree featuring Francesco Roma Marzio.

Photo by Andrew S. Mathews.

Drawing is the method through which I do justice to this mundane ontological indeterminacy. The form of a cultivated chestnut tree tells me a story of 
its responses to encounters with peasants, diseases, fires, and soil movement processes. I draw this form in different ways, depending on whether I notice the details of disease cankers and imagine that this tree is doomed or whether I infer that it is on its way to a new symbiosis with disease-causing organisms when I notice new shoots and the scarring produced by disease containment. From these encounters I learn to produce a drawing that summarizes my perception of human-plant and plant-nonhuman interaction as they manifest in tree form. Sometimes I accompany this drawing with the linguistic terms that sharpen my capacity to notice some differences and not others. My sensory apparatus is transformed by my own curiosity and by my journeys with farmers and foresters. They teach me words that change my sense of landscape patterns and my capacity to notice tree form. Figure 4, below, comes from a conversation and forest walk with the young farmer Stefano Fazzi. Stefano taught me to see the different bark textures above, below, and around a graft scar, to name the parts of the tree accordingly. Stefano can recognize chestnut varieties on his Apennine hillsides at a glance, something that even the most expert botanists cannot always do. My encounters with Stefano's trees and stories have permanently changed my sensory capacities. I cannot see trees in the same way now, as I learn new words and new ways of noticing texture and form. My capacity to notice is, however, not fully contained or tamed by the words I learn from Stefano, Francesco, or from foresters and scientists. Their words are provisional, and they capture some aspect of the indeterminacy and shimmer of strange ontologies, but my perceptions may shift. I might need to tell still other stories with other words.

Multistemmed trees tell me of practices of peasant firewood cutting, known as ceduo (coppicing), and of the capacity of these trees to resprout from a stump or ceppo (see Figure 5). Conifer plantations at the top of the mountain tell me of struggles between the Italian state and pastoralists. From the late nineteenth century onward, but especially during the Fascist regime of Benito Mussolini (1922-1943), the national forest service saw the fires set by pastoralists as a grave threat to the forests. Grazing and pastoral burning were ubiquitous and, in theory, heavily penalized, although in practice widespread and somewhat tolerated. From the late 1940s until the early 1980s, Cold War and then less militarized national reforestation programs tried to redeem these contested mountain pastures. Throughout this period, foresters saw tall and straight conifer trees as valuable and scientifically manageable, as a way of providing rural employment, producing timber, and halting environmental degradation. Later, these plantations were seen as a solution to the rural agricultural abandonment engendered by industrialization 


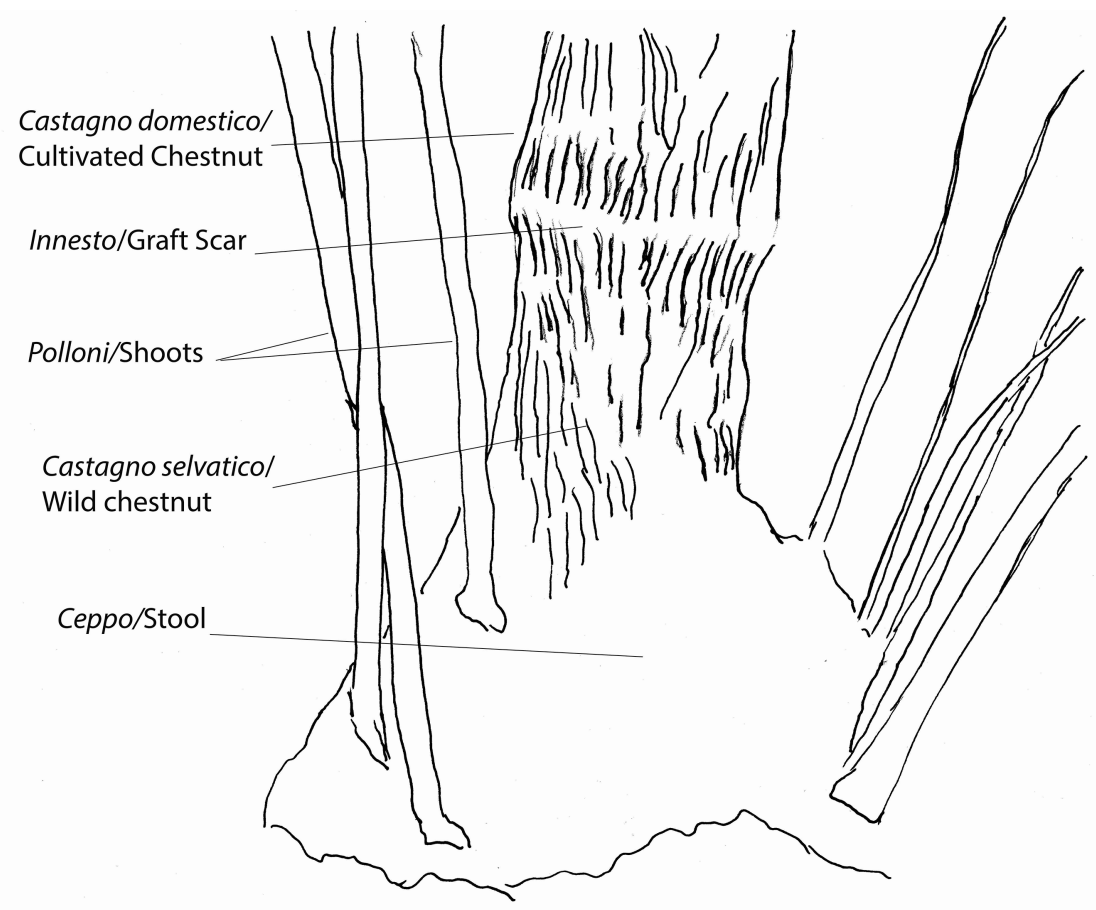

Figure 4. Drawing of a cultivated chestnut tree. Image and text by Andrew S. Mathews.

and urbanization. For Alessandra del Chiaro, the daughter of a peasant smallholder, Douglas fir (Pseudotsuga menziesii) plantations near her farm lower down the mountain were a tax boondoggle for rich landowners, an ecological mistake.

Power-laden histories of natural-resource extraction and state-making leave traces on tree and landscape form. Even as we notice the details of plant form, my companions and I often discuss history, politics, state-making, and global environmental change. Francesco can recognize the multitude of understory plants (I cannot do this): he names native species and notices more recent alien arrivals, leading us to wonder about international trade and transportation networks. When we encounter old pastures covered with conifer plantations, Francesco notices the meadow species Crocus biflorus, which is unpalatable to cattle and sheep, hanging on beneath the conifers loved by the forest service. The persistence of these pasture flowers is a trace of the centuries of grazing by sheep and goats who would have avoided eating unpalatable plants and grasses. Stories of sheep, grazing, and pastures launch Francesco and me into conversations about the displace- 
ment of pastoralists by the forest service. He tells me of the contented outdoor life of his shepherd grandfather in Puglia, who lived into his nineties.

Walking and paying attention to color, shape, and form press me to be alert both to textures (the background, which remains indeterminate) and to the emergent forms that come to matter (the foreground), which I highlight through sketches and drawings. A few pencil strokes can summarize the patterns that I notice when I take a picture. These line drawings can be the shapes of trees whose ontology is indeterminate, of field boundaries, or of larger landscape patches whose boundaries could be drawn otherwise, perhaps in relation to encounters with details that have come to have a larger significance. In many cases, patterns such as plant form gesture toward processes that I cannot see. A line drawing makes visible my relationship with a particular tree or terrace, my effort to show that this was a partial relation that failed to grasp other aspects of a chestnut stump that might live or die or change shape over time. A strong tradition of line drawings exists in archaeology, natural history, and field biology (Canfield 2011), as well as, formerly, in cultural anthropology (Evans-Pritchard 1940; Lévi-Strauss 1955). Because of the nature of their material, archaeologists have never abandoned drawings of changing animal anatomy or seed morphology as an important way of tracing histories of domestication that tell of human-nonhuman relationality. Similarly, biologists continue to use drawings to highlight the key features that they track in telling stories about evolution and adaptation. ${ }^{7}$ Cultural anthropologists, I suggest, might think of line drawing as a method appropriate to recording morphologies that emerge from relationalities across ontological and temporal difference, and to their own involvement with more-than-human beings.

\section{SHAPE CHANGERS IN THE FOREST}

Trees are long-lived shape changers; their form records biographies of survival in the face of fire, disease, grazing, and human cutting, lopping, and pruning. Becoming attuned to tree form makes me notice the bizarre inventiveness of plants that change shape and move across the landscape too slowly for me to notice easily. The drawings in Figure 5 make visible some of the different forms that chestnut trees can take. ${ }^{8}$ Names for these forms emerged from the daily work of peasant farmers who worked with plant-soil-animal assemblages, and from conversations between peasant cultivators and the officials and literati who occasionally talked to them. In Italy, a host of traditional technical terms for chestnut trees, terraces, and forests are now falling into disuse, known mainly to old people as well as historians, foresters, and anthropologists like me. Old words tell of old 
relationships, but new words and plant varieties are also always potentially coming into existence from acts of noticing and care. In the winter of 2014, the farmer Stefano Fazzi, who lived in the nearby Garfagnana area, told me that he had noticed that a particular chestnut variety on his land appeared immune to the invasive gall wasp Dryocosmus kuriphilus, a pest that was devastating chestnut production in the region. Stefano hoped to have his variety recognized and named, and to build collaborations with the academic establishment and the state. This was a speculative Anthropocene political project, a way of resisting an invasive disease and perhaps also of adding to his livelihood.

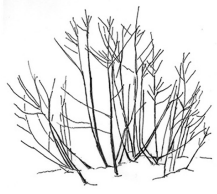

Shoots/polloni resprouting from a stool/ceppo, about 2-4 years old

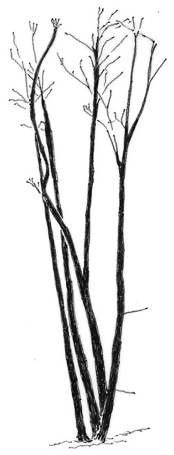

Twenty year old coppice suitable for firewood/poles $5 / 8$ stems per stool/ceppo.

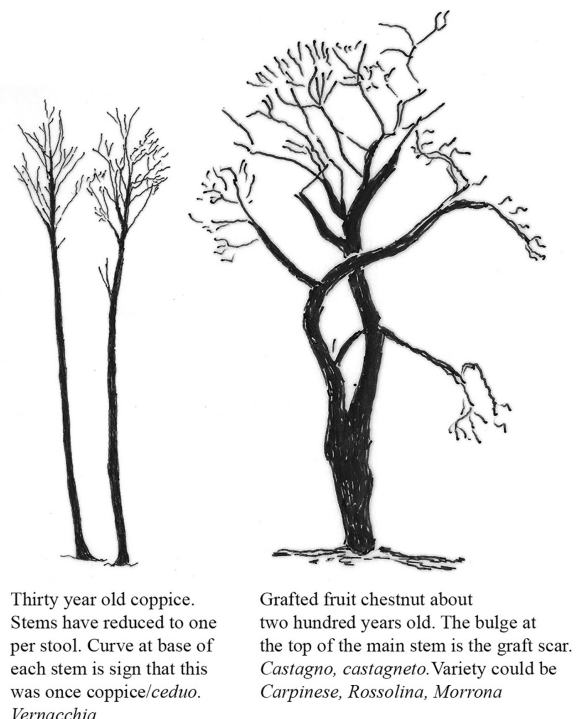

Vernacchia

Figure 5. A menagerie of chestnut forms. Images and text by Andrew S. Mathews.

These drawings emerged from days of walking across forest landscapes, of learning to notice the strange details that inhabit mundane perceptions, and from many conversations about these landscapes with farmers, officials, and others. The drawings come from photographs of particular trees and were often linked to the moment when I was taught a particular word. Vernacchia came to me when walking with the smallholder Francesca del Chiaro and the plant scientist Massimo Giambastiani in February 2014. Massimo is a biologist concerned with protecting traditional chestnut varieties. He showed me ancient chestnut trees in a final state of abandonment, mourning the loss of traditional cultivated varieties. Francesca's aged father Giuseppe grows prized chestnut varieties on old olive terraces near 
their house on the slopes of the mountains. For both of them, histories of peasant tree care inspire a politics of caring about the shapes of trees, of maintaining plant varieties, and of respecting peasant knowledge. The drawing of ceduo came to me on a field trip with government foresters, who told me how this multistemmed plant might become a tall single-stemmed tree (ceduo affrancato). ${ }^{9}$ Italian foresters love the idea of tall straight trees (ideally conifers), and historically they have tried to avoid the gnarled fruit trees or the multistemmed firewood forests desired by peasant farmers. Farmers and peasants told me that to allow trees to grow too large was to risk having them classified as high forest (alto fusto), which might become bureaucratically impossible to cut and which might destabilize hillsides and terraces. My drawings are as much concepts as representations, then: they contain contested futures, they include my guess at how I can best communicate what I see (as a forester with a lifelong practice of walking landscapes) or have been taught to see by others. These drawings come from highly atypical photographs in which I have removed a tree from its context with other trees; no photograph can communicate what the skilled eye learns to see. Photographs are too realistic, almost the worst way of communicating stories about form. My seeing emerges from walking, talking, touching, and wondering; each drawing is a diagram, a story, a description.

Like tree forms, terracing systems come in many shapes and have many names. These are easier to see in photographs (see Figures 6 and 7 below). Terraces and banks, which keep soil from washing downhill, are forms that emerged from peasant cultivators' attention to plant form, a geomorphological consequence of their attention to plant morphology. When plant roots were washed clean, the plants failed to flourish; peasants responded by building terraces (Mazzarosa 1846, 101). Terracing came into being for many reasons, from capitalist investment to competitive display, but the most important factor was peasant farmers' noticing the capacity of plants to gesture toward soil quality and water availability, processes that humans only dimly perceive. Terrace and plant form gave rise to a rich vocabulary, to strong affective and aesthetic associations and to moral judgments. Just as trees have many names for the many forms that have emerged from plant biographies, so too do terraces (Pedreschi 1963).

Terrazzamento (terrace) is a relatively recent word. Older and more precise terms are now known to only a few people, as I learned when driving around the Monti Pisani with Fabio Casella. Fabio is a municipal planning official who grew up in a peasant household on the Monti Pisani and whose lifelong passion has been maintaining pastures, terraces, and drainage systems (Rizzo et al. 2009). 


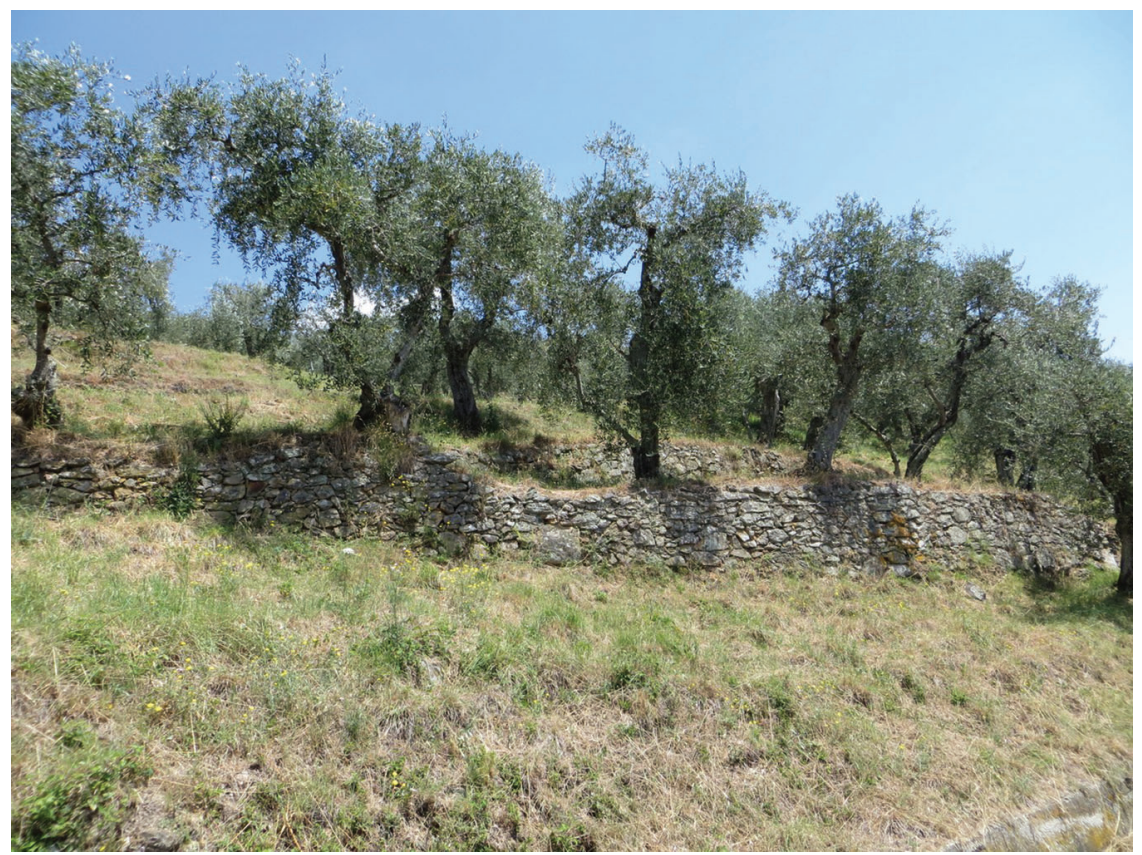

Figure 6. Stone terraces with olive trees, Calci, Lucca, 2016. Photo by Andrew S. Mathews.

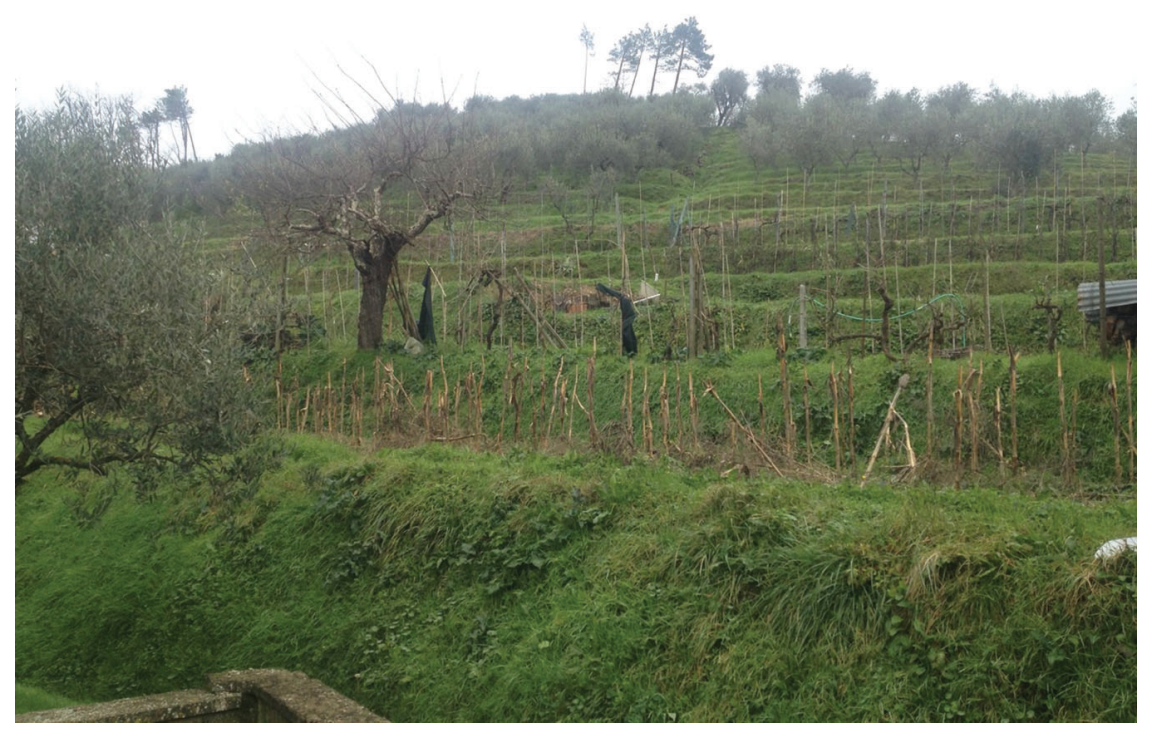

Figure 7. Earthen terraces, San Andrea del Compito, 2014. Photo by Andrew S. Mathews. 
Fabio remembers firewood cutting and sheep grazing, and he names the kinds of terraces as he points them out to me. He reminds me that terraces are also always drainage systems, complex soil-water choreographies that take continual care. Fabio is deeply concerned at the dramatic increase of fires and the expansion of the fire-prone pine species pino marittimo (Pinus pinaster) across the Monti Pisani. Stone firebreaks at the edge of old terraces kept fires in check, grazing kept pastures clear of trees that might burn, and litter raking made forests less flammable. For Fabio the repetitive and rather monotonous landscape of pines signals loss and the threat of fire, or the landslides that might follow fire or terrace abandonment. Where pines and chestnut trees mix, he and I both notice the older landscape pattern of ceduo or castagneto. Fabio's practices of terrace care constitute an Anthropocene landscape politics that links the details of terracing systems and grazing to forest fires, landscape stability, and global environmental change.

\section{HISTORICAL ECOLOGY: Linking Natural History, Cadastral Maps, and Oral Histories}

My natural-history observations and sketches, drawn from walking across the Monti Pisani and from conversations with many different companions, gave me a good sense of the present-day forest, haunted by the physical, linguistic, and imaginative traces of past cultivation. Early nineteenth-century cadastral tax maps gave me a very different account, registering traces of encounters between tax collectors, landowners, and peasants who tried to manage multispecies choreographies on these landscapes. Cadastral mapping projects tried to record who owned each piece of land and how the land was being used, with the aim of increasing taxation and propelling capitalist investment in buildings, infrastructure, or improved cultivation. In the tax records I found traces of encounters between landowners and the peasants who cultivated land on their behalf. We can hear something of the words they shared to talk about complex polycultural cultivation systems, ranging from chiuse (walled gardens) cultivated with mixtures of vigne a pergola (trellised vines) at the bottom of the valley to ceppato di castagno (coppiced chestnut), castagneto, pascolo (pasture), and pineta (pine forest) (Catasto Vecchio 1843). These descriptions emerged from a meeting between the tax assessor, who was also usually a local landowner (Massoni 1999, 255-56), and the estate manager, peasant sharecropper, or small farmer who managed the land. These records preserve traces of an intimate relationship between plant mixtures and the peasant managers who described them, and between these peasants and landowner/tax assessors who estimated the value of crops. Drawing on this tax 
register, I can compare the forms of plant cultivation in 1843 with what I saw during my walks in 2014.
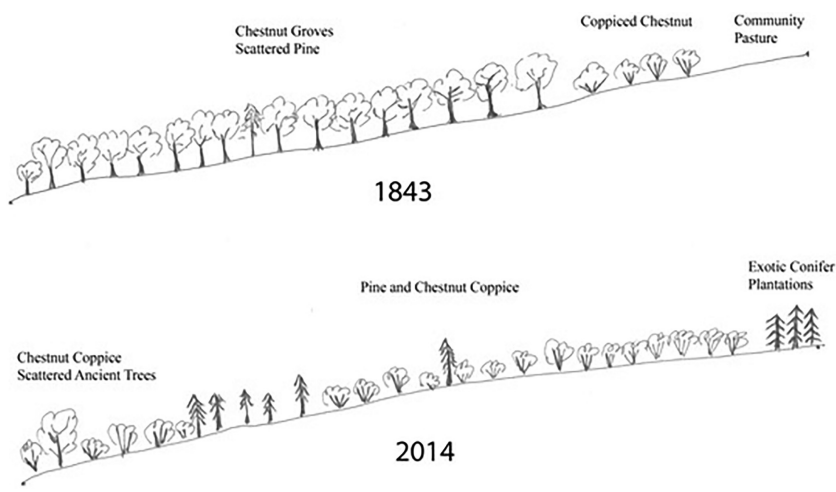

Figure 8. Comparing forests in 1843 and 2014: dominant tree forms on a transect walk from Cima di Vorno to Monte Faeta, Lucca. Images by Andrew S. Mathews.

This drawing is an empirical diagram resulting from my walks and conversations with Francesco, from interviews with foresters, farmers, and officials, ${ }^{10}$ and from visits to the Archivio di Stato in Lucca. This drawing records histories of ruination, disastrous pathogen outbreaks, and the slower disaster of capitalism. In 1843 the landscape was dominated by castagneto with some pineta, a smaller area of ceduo managed for firewood, and a communal pasture at the top of the mountain. In 2014 the castagneto is almost entirely gone, pino marittimo occupies many areas, and chestnut ceduo covers most of the rest. At the top of the mountain exotic conifer plantations (Pinus nigra, Cedrus libani) have replaced the former common pasture. In many sections, pino marittimo has completely taken over, with scrubby stumps of ancient chestnuts lingering in an understory dominated by bracken (Pteridium aquilinum), with occasional manna ash (Fraxinus ornia), arbutus (Arbutus unedo) and, on drier and higher areas, drought-adapted species (Juniperus and Ulex). Often Francesco and I would see ruined metati (chestnut smoking sheds) and abandoned terraces in areas now covered by pine forest. The conifer plantations at the top of the mountain are the last echo of Cold War workfare programs that sought to prevent peasants from becoming communists. Old people tell of the fines that the forest service used to impose on pastoralists, of the hard work of planting trees. Some of the ceduo is still cut for domestic firewood, but much is destined to become wood chips for biomass energy production, an effort to stave off the slow disaster of climate change. 


\section{SEEING THROUGHSCAPES: Ink Disease, Industrialization, and Forest Fires}

Plant forms emerge as a result of biographies of individuals and their histories of encounter with other beings: firewood cutters, fires, or epidemic pathogens. By walking across many parts of the landscape, my encounters with individual organisms taught me to perceive larger-scale landscape patterns and to wonder about the causal forces that brought these patterns into existence. I will briefly describe two throughscapes, landscape patterns that literally overlap and sit through each other.

\section{History 1: Ink disease. Cutting peasant-sheep-chestnut assemblages}

The scattered ancient chestnut stumps with emerging sprouts are the survivors of the pathogen Phytopthora cambivora, which arrived here in the 1850s and destroyed low-elevation chestnut orchards, leaving only a few scattered surviving trees. Plant scientists and peasants told me that Phytopthora strikes like a fulmine (lightning bolt), killing trees from the roots to the crown in a matter of weeks. Affected chestnut trees produced a foul-smelling black liquid in their roots, giving rise to the name male del inchiostro (ink disease), causing wholesale abandonment of chestnut cultivation at lower elevations (Gibelli 1883; Cipolloni 1893; Bonucelli 1939) and allowing other tree species (not only pino marittimo) to colonize the landscape. By the 1930s the male del inchiostro had declined in virulence, perhaps as the ectomycorrhizal associates of trees learned to form less destructive associations with it (Blom et al. 2009). Chestnut ceduo and castagneto persisted at higher elevations where the pathogen did not strike. The spread of Phytopthora around the world in the 1840 s can be attributed to the unintended impact of nineteenth-century international trade, whose road networks and ports enabled the journeys of pathogens.

In this account, peasants, trees, and soils, ectomycorrhizae and Phytopthora are key actors who mutually transformed each other in unexpected ways. It would be easy to tell a history of invasive disease destroying an agro-ecological system, beginning with the arrival of the ink disease in the 1850 s and ending on a note of cautious optimism inspired by the remnant chestnut trees clinging to the upper slopes of the Monti Pisani. This is certainly part of the story; it captures some part of the relations among people, trees, soils, and Phytopthora. This storyline is accountable to the remnant low-elevation chestnut trees loved by Massimo and Alessandra, to the much larger areas of castagneto recorded in the tax registers, and to the ruined metati scattered across the landscape. The storyline, however, 
remains partial: in highlighting the material traces and absences produced by chestnut disease and international trade, it fails to notice a completely different pattern of presence and absence.

\section{History 2: Industrialization and wildfire. Cutting peasant-sheep-leaf- litter assemblages}

A different history starts fifty years earlier, around 1800, and is linked to capitalism and industrialization. This history tells of the disaggregation of the urban metabolism from the forests that formerly supplied fuel and fertilizer. It tells of the transformation from sharecropping peasants - whose care of sheep linked forest leaf-litter raking with fields, whose firewood cutting and charcoal burning supplied home heating - into industrial and now postindustrial workers. Already in the early 1800s, many people in Vorno, as in other towns around the Monti Pisani, were working in the flour, paper, paint, and gunpowder mills that clustered along the streams running down from the mountains (Massoni 1999). By the 1860 s, this water-powered industrialization was in full swing, not to be displaced until the arrival of oil-powered industrialization after World War II. ${ }^{11}$ From the 1950s onward, the breakup of large estates on the lower slopes of the Monti Pisani allowed some sharecroppers to buy their land and become small farmers; others worked in factories. The next generation is increasingly one of postindustrial workers or workers in rural tourism. Some of them maintain gardens or cut firewood, but sheep grazing and litter-raking have completely disappeared from the Monti Pisani. This absence also produces material presences: thick litter layers on forest floors, fire scars, burn areas, fire roads cut by volunteer firefighters or the forest service. This history tells of the long struggle of sharecroppers to scrape a living out of difficult soils in the face of sometimes oppressive landlords, of how some of these sharecroppers became smallholders (like Francesca's father) while others emigrated to cities or became industrial workers or officials (like Fabio Casella).

This history, of capitalism dissolving peasant labor practices, which had linked trees, sheep, grass, and landscape form, has various conjunctures and moments of rapid change. Perhaps the most telling conjuncture for this particular landscape was the shift from animal-plant fertilizer to chemical fertilizer. ${ }^{12}$ Until the 1960s, peasants used to rake leaf litter in the forests and carry it downhill to terraces, where, combined with animal dung, it became valued fertilizer. ${ }^{13}$ One old farmer told me how the color of an entire hillside had changed from the red of his youth to the present-day green, as the backbreaking work of carrying baskets 
of leaf litter disappeared into memory. Younger volunteer firefighters told me how large-scale forest fires arrived in the mid-1970s, about fifteen years after the abandonment of sheep grazing and litter raking. Casella had collaborated with a fire scientist to experiment with restoring burning to the crest of the mountains in an effort to reduce at least the size and intensity of wildfires, which had caused the expansion of fire-adapted pino marittimo. This second landscape pattern, of the rather monotonous pine forest that dominates lower and medium elevations, especially on the southern side of the mountains, is accountable not to stories of disease and global trade, but to labor practices in fields and factories, to urban metabolism, and to the former linkages among sheep, fertilizer, leaf litter, and labor. When Casella points to the deep leaf litter that makes forests flammable, he teaches me also to notice absences: of sheep, goats, and of the peasants who worked with them.

A final force for landscape transformation linked to industrialization is a second disease, the chestnut cancer (Chryphonectria parasitica), which arrived in this area in the 1950s. Faced with this new pathogen, many farmers decided to sell the remnant higher-elevation chestnut groves that had survived the male del inchiostro to nearby tannin factories, which literally devoured ancient trees. Like the ink disease, chestnut cancer was eventually slowed down by its own accumulation of relationships with other beings. In this case, the cancer acquired its own virus, which made it no longer lethal. Logging for tannin production did not kill trees, but it transformed remaining chestnut orchards into ceduo.

In Figures 9 and 10 you can see something of what I learned to see through my close encounters with pines and chestnuts and through my conversations with companions who taught me words that had emerged from practices of care and cultivation. From these encounters, I am pressed to see two different, provisionally stable throughscapes that lie through each other. By being near and close to particular trees, I learned to see color and texture so that a few days later, when I looked back at the Monti Pisani, my eyes were attuned to the particular reddish color of chestnut buds (light gray) and the gray-blue of pino marittimo (dark gray) (Figure 9). As you can see, light and dark gray are mixed, but two landscape patterns are clearly visible, even as these patterns literally mix and lie through each other. My encounters with farmers and archives, my walking and noticing, had helped me perceive different patterns and histories. The pattern of remnant chestnut forest dominated by ancient trees and living stumps is linked to histories of international trade, peasant tree care, plant disease, and emerging symbioses between pathogens, plants, and microorganisms. The areas of pine forest are 


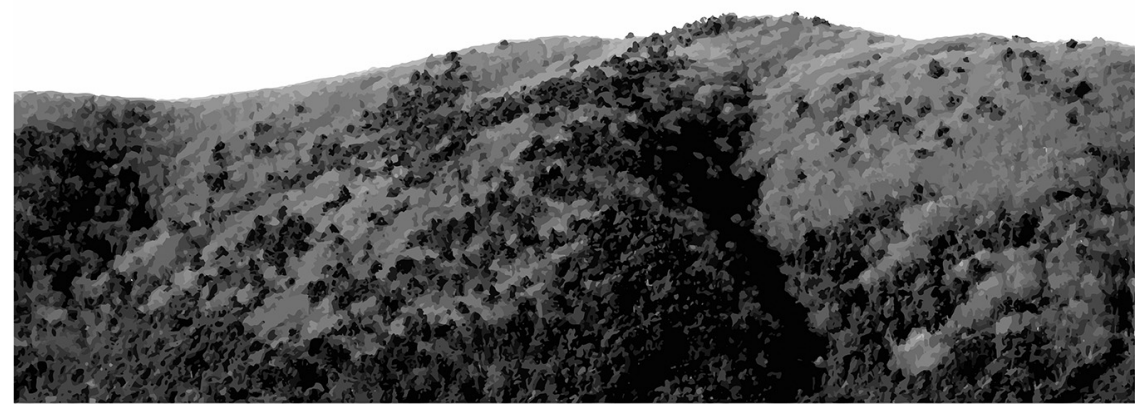

Figure 9. Detail from photo of Monti Pisani, with pine shown in dark grey and chestnut in light grey. Image by Andrew S. Mathews.

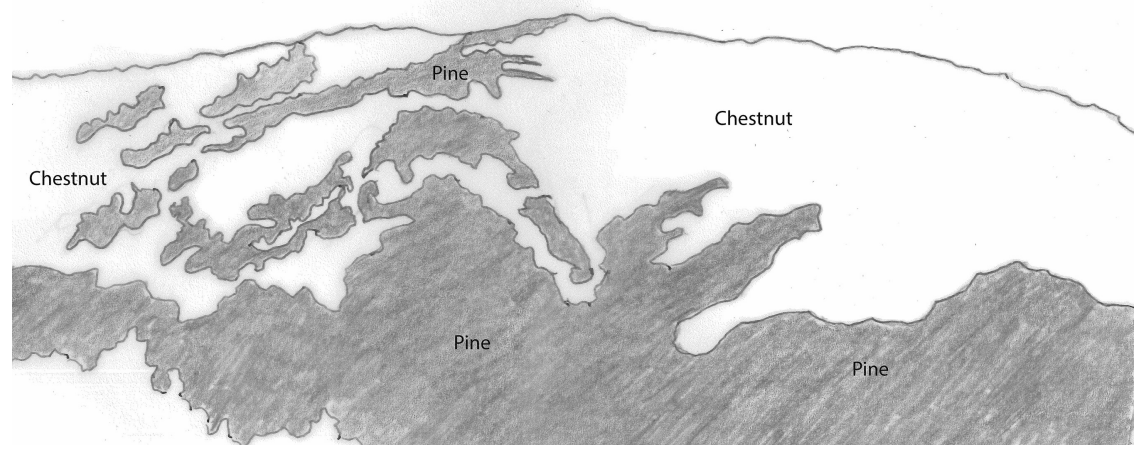

Figure 10. Chestnut and pine throughscapes on Monti Pisani. Image by Andrew S. Mathews.

linked to the absence of sheep and peasants who formerly raked leaf litter, as well as to the recent forest fires that help young pines expand across the landscape. There is a continuous cross-talk between my close encounters with particular trees or ruins and my large-scale experiences of landscape patterns. By tacking back and forth between farmers and officials, between visits to the archive and 
walking, noticing, and speculating, I devise storylines linked to my perception of throughscapes, of patterns that contain multiplicities and mixtures. Throughscapes overlap and lie through each other; they organize perception and anchor histories, but they are also somewhat provisional. The drawing in Figure 10 could be redrawn in many ways: the lines are both perceptions and concepts that give rise to theories.

\section{CONCLUSION}

In this essay I have described how I use methods drawn from natural history, oral history, landscape walks and interviews, and archival research, as well as from my own phenomenological experience of walking and noticing, to recount multiple histories of landscape change. These histories proceed at different rates in relation to different causes, and they have produced different landscape patterns in the present. I have suggested that reading landscape in this way makes visible multiple throughscapes, landscape patterns that lie through each other, are partially connected to each other, but are structured by particular more-than-human relations and proceed according to their own rhythms. As Anna Tsing pointed out to me, throughscapes are different ontologies and infrastructures that coexist with one another even if they have different histories. One throughscape is the rapidly changing postpeasant landscape of pine and fire, which is strongly linked to histories of capitalism and industrialization. The other is a much slower, changing postdisease chestnut landscape linked to longer histories of biological exchange and international trade. These throughscapes have considerable consistency of species composition and tree form; this repetitiveness could allow us to think of them as a kind of infrastructure (see Carse 2014).

Much discussion of ontologies in recent anthropological debates has highlighted the incommensurability of radically different ontologies and temporalities, as in Marisol de la Cadena's (2010) work on Andean earth beings, which lie outside of history and are rendered unthinkable by the state. Something like this noncommunication between ontologies took place in Italian forestry officials' attachment to conifer plantations and their hostility to the pastoral burning that formerly produced fire-resistant landscapes across the Mediterranean (Cevasco and Moreno 2013). Maintaining this kind of incommensurability takes ongoing political work (Dove 1983; Mathews 2005). In the account I give here, however, I point not to incommensurability across political-ontological differences, but to the mundane practices through which I learned to perceive multiple ontologies, histories, and the throughscapes that I could perceive at the same time. Analogous 
methods could be used to notice multiple coexisting throughscapes in other places entirely, from urban spaces to industrial farms.

Each throughscape has a different storyline, a history with a different beginning, with different actors that change as a result of relationships with each other, and with spatial patterns that emerge differently at various scales. These throughscapes are not linked to a single history, but to multiple histories that emerge from my practice of attending to processes that proceed with very different rhythms, from rapidly moving fires to slower moving diseases and symbioses. Landscapes are an interesting kind of thing here: they are quasi-objects, perceptual categories inhabited by a multiplicity of relations between living and nonliving beings, but they are also phenomenologically real; they have a certain color and texture and an instantly recognizable form, a repeated infrastructural pattern of abandoned chestnut groves or of fire-blasted pine forests. Landscape patches are approximate, containing shifting assemblages of humans and nonhumans (Tsing 2015, 394). At the same time, they are concrete, recognizable, and linked to political and economic formations and histories (Olwig 1996).

In the account I have given of the Monti Pisani, histories and ontologies are multiple. Each history is partial, so we can simultaneously entertain multiple histories and the provisionally stable landscape patterns to which I have linked them. These histories emerge from my practice of tacking back and forth between forest walks, scarred trees, conversations with farmers, and visits to the archive. Unlike the classic facts of science and technology studies, which are stabilized by assenting witnesses and the networks in which they come to participate (or that admit to difference as realized through site-specific practices), this kind of knowledge of the landscape is inherently multiple across the same landscape and is always potentially unstable when details come to tell stories at other scales. In the Monti Pisani, knowledge of the landscape of large-scale patterns of ancient chestnut orchards is always potentially remade by small patterns on individual trees, such as disease or graft scars. A dying tree can change my understanding of a whole landscape; my sudden perception of blocks of conifer plantations may lead me to ask farmers and archives about these state-sponsored interventions. Just as every drawing is a form that contains indeterminacy and multiplicity, so too my histories coexist with other histories and rhythms, possible patterns that are both empirically real and provisional, containing details that could change perceptions of patterns at other scales.

Ethnoecologists and scholars of traditional and indigenous ecological knowledge have long described the existence of rich domains of classification in areas 
of particular interest and practical work, as in E. E. Evans-Pritchard's (1940) work on cattle or Harold Conklin's $(1955,1957)$ work on Hanunó'o farmers. Other scholars have described how cultigens and the memories of their use are retained or lost (Nazarea 2006). In this essay the historical depth of my evidence has allowed me to trace the emergence and disappearance of particular forms of noticing and linguistic description, as changing work practices cause words for tree form, terraces, or plant varieties to emerge or recede from common knowledge. These processes of emergence and disappearance resonate with the incomplete descriptions through which I learned to see and draw tree form and landscape pattern in the Monti Pisani. Descriptions and classifications are always partial, both grasping and failing to grasp the world. Involutionary encounters with particular beings literally draw me and my interlocutors in. ${ }^{14}$ These encounters sometimes demand particular words to refer to plant forms or landscape patterns, across local communities of practice or bureaucratic state-making. These plant forms are always partial, containing indeterminacy alongside what is resolved and perceived.

In the Monti Pisani, different Anthropocenes inspire projects of landscape restoration that draw on specific landscape histories to craft speculative, hopeful, and deeply political imagined futures. Volunteer firefighters, inspired by their retelling of the impacts of the abandonment of pastoralism and litter raking, now talk of restoring burning to the crests of the Monti Pisani. Another Anthropocene politics is advocated by the biologist Massimo Giambastiani, who seeks to preserve low-elevation chestnut varieties that will be more resilient in the face of climate change. Opponents of large biomass electricity plants in nearby Bagni di Lucca draw on the charisma and legitimacy of peasant firewood cutters to demand energy systems that feed local uses of heat energy, rather than supporting large plants that will power the national electricity grid. In each case, the historic forms and uses of the landscape animate future-oriented politics. Each of these Anthropocene political projects draws on histories of peasant experimentation and landscape use. None tries to reproduce the past; each seeks to make a livable present or prepare for future disaster. Similarly, the political ecologies that have arisen in response to imperial and postcolonial projects of landscape transformation in the global South have always been political responses to one or another Anthropocene. These political ecologies are not a depoliticized and singular managerial Anthropocene, but multiple, deeply political Anthropocenes that are linked to different landscape histories and futures. 
Recent years have seen a heated debate about how to date the Anthropocene. Scholars have argued over whether the best date is the Columbian exchange (when Old and New World plants, animals, and diseases met each other), the Neolithic origins of agriculture, the Industrial Revolution, or the 1945 atomic bomb test in New Mexico (Swanson 2017). A related discussion carried out mainly by humanists has focused on the risks and dangers of particular namings, asking whether the term Anthropocene inappropriately highlights the power and imagination of humans, or of particular humans, or if perhaps it silences the role of capitalism (Haraway 2016). These debates are valuable, but I argue that attention to landscapes and phenomenologies of encounter draws us toward the concept not of a singular Anthropocene, but of multiple Anthropocenes that coexist with each other. We can think of these Anthropocenes as having multiple beginnings and storylines, each of which leaves much unseen. We can cultivate a dramatic form of attention that sustains multiple, competing stories of social and ecological change, of encounters between people, plants, soils, and diseases, while remaining alert to the limits of each account, to the excess that it fails to capture. Ecological modelers, earth-systems scientists, and their humanist critics have been too hasty to assume that the Anthropocene is one process and that it must begin at one particular time. If we are willing to notice multiple Anthropocene temporal rhythms and overlapping throughscapes, we are closer to the kinds of events that multiple histories tell us. Each history (like each ecological model) captures some aspect of the irreducible complexity of the world; each history follows the transformations and relations of particular beings while paying less attention to others; each ecological model is a partial account that encounters irreducible indeterminacy. Dramatic modes of attention are good to think with here. When we watch a play, we are able to imagine that each character has a point of view, and we are willing to be entertained by a wholly unrealistic situation. Drama requires and makes visible the imagination of the audience; it stages a multiplicity of coherent but partial worldviews, without demanding that the viewer choose one character as having the right vision of the world. In telling accounts of Anthropocene landscapes in Italy, I have drawn from the histories and biographies of particular plants, pathogens, and economic systems. I have laid out a partial but coherent account of several among many Anthropocenes, while allowing myself to entertain still other Anthropocene dramas. 


\section{ABSTRACT}

Phenomenological descriptions of landscapes, trees, and terraces, combined with oral history and historical ecology, find traces of industrialization, plant disease, and forest fires in central Italian forests. Plant form, landscape form, and forest structure can be described through drawings that give resolutely partial descriptions of morethan-human encounters. This kind of knowledge of the landscape is potentially unstable and remade by the details that it contains. By using multiple methods for attending to more-than-human landscapes, we can learn to notice multiple throughscapes, landscape patterns that overlap and lie through each other, but which are linked to different histories. Multiplying histories means that rather than being seen as a single era, the Anthropocene can be understood as having many beginnings and coexisting histories that give rise to multiple futures. [forests; landscapes; pathogens; Anthropocene; Italy]

\section{NOTES}

Acknowledgments Research for this article was carried out during sixteen months of fieldwork in 2013-2014, and in the summers of 2015 and 2016. Earlier versions of this material were presented to the Center for Advanced Study on Arctic Domestication in the Era of the Anthropocene at the Norwegian Academy of Sciences in 2015 and 2016. Marianne Lien and Nils Bubandt generously and carefully read earlier drafts. I have talked through many versions of these ideas with Anna Tsing.

1. The term Anthropocene was coined by Paul Crutzen and Eugene Stoermer (2000) and has given rise to a diverse set of responses from the natural sciences, social sciences, and humanities. For a review of some recent approaches in the humanities and social sciences, see Swanson, Bubandt, and Tsing 2015.

2. The term peasant is deeply loaded. In what follows, I use it to describe someone who might have identified themselves as a contadino. I use the term farmer for contemporary smallholders.

3. Debates about ontologies have created much controversy during the past few years (Bessire and Bond 2014; Blaser 2014). In this essay I focus on the ontologies that emerge through particular practices (Lien and Law 2011).

4. Ecological and climate modelers are very familiar with this kind of scale-jumping, and seek to constrain it through practices of parametrization and tuning (Edwards 2010)

5. Infrastructure studies comprise a large and diverse literature (see Larkin 2013). An early canonical formulation was provided by the feminist scholar Susan Leigh Star (1999).

6. For a brilliant discussion of how we craft "time machines" by building relationships between particular nonhumans, see Elaine Gan's (2017) work on rice in Southeast Asia.

7. I was inspired to plunge into drawing by a conversation with the biologist Peter Funk.

8. Here, I affectionately acknowledge the drawings of Oliver Rackham (Grove and Rackham 2001).

9. Affrancato literally means "freed." It is telling that foresters see high forest as a kind of enfranchisement from servitude to peasant ceduo.

10. Numerous interviews in 2015 and 2016 were carried out in collaboration with the anthropologist Fabio Malfatti.

11. For an account of water-powered industrialization in southern Italy, see Barca 2010. On hydroelectricity across Italy, see Armiero 2011.

12. Well-matured night soil, bottino, from the city of Lucca was used as fertilizer well into the 1950s.

13. Litter raking was formerly ubiquitous across central and southern Europe (Gimmi et 
al. 2013). In Italy this practice has passed almost unrecorded in forestry regulations, and was only picked up by ethnographic methods.

14. Although coming from a different tradition, these findings resonate with scholarship on affect, which highlights attunement to "the forms and forces unfolding in scenes and encounters" (Stewart 2017, 192).

\section{REFERENCES}

Armiero, Marco

2011 A Rugged Nation: Mountains and the Making of Modern Italy. Cambridge: White Horse Press.

Barad, Karen

2003 "Posthumanist Performativity: Toward an Understanding of How Matter Comes

Barca, Stefania to Matter." Signs 28, no. 3: 801-831. https://doi.org/10.1086/345321.

2010 Enclosing Water: Nature and Political Economy in a Mediterranean Valley, 1796-1916. Cambridge: White Horse Press.

Barnes, Jessica

2014 Cultivating the Nile: The Everyday Politics of Water in Egypt. Durham, N.C.: Duke University Press.

Berger, John

1973 Ways of Seeing. New York: Vintage. Originally published in 1972.

Bessire, Lucas, and David Bond

2014 "Ontological Anthropology and the Deferral of Critique." American Ethnologist 41, no. 3: 440-56. https://doi.org/10.1111/amet.12083.

Blaser, Mario

2014 "Ontology and Indigeneity: On the Political Ontology of Heterogeneous Assemblages." Cultural Geographies 21, no. 1: 49-58. https://doi.org/10.1177/ 1474474012462534.

Blom, Jan Maarten, Andrea Vannini, Anna Maria Vettraino, Michael D. Hale, and Douglas

L. Godbold

2009 "Ectomycorrhizal Community Structure in a Healthy and a Phytophthora-Infected Chestnut (Castanea sativa Mill.) Stand in Central Italy." Mycorrhiza 20, no. 1: 2538. https://doi.org/10.1007/s00572-009-0256-z.

Bonucelli, Pio Fortunato

1939 "Il castagno nella Lucchesia." Atti della Reale Accademia Lucchese 17: 2-26.

Braudel, Fernand

1972-1973 The Mediterranean and the Mediterranean World in the Age of Philip II. 2 Callon, Michel volumes. Translated by Sian Reynolds. New York: Harper and Row.

1986 "Some Elements of a Sociology of Translation: Domestication of the Scallops and the Fishermen of St. Brieuc Bay." In Power, Action, and Belief: A New Sociology of Knowledge?, edited by John Law, 196-233. Boston, Mass.: Routledge and Kegan Paul.

Canfield, Michael R., ed.

2011 Field Notes on Science and Nature. Cambridge, Mass.: Harvard University Press. Carse, Ashley

2014 Beyond the Big Ditch: Politics, Ecology, and Infrastructure at the Panama Canal.

Catasto Vecchio Cambridge, Mass.: MIT Press.

1843 Giornale di campagna. Antico Catasto Borbonico, Archivio di Stato di Lucca.

Cevasco, Roberta, and Diego Moreno

2013 "Rural Landscapes: The Historical Roots of Biodiversity." In Italian Historical Rural Landscapes: Cultural Values for the Environment and Rural Development, edited by Mauro Agnoletti, 141-52. New York: Springer. 
Chu, Julie Y.

2014 "When Infrastructures Attack: The Workings of Disrepair in China." American Ethnologist 41, no. 2: 351-67. https://doi.org/10.1111/amet.12080.

Cipolloni, Francesco

1893 "La decadenza del bosco nei Monti Pisani e modi pratici di provvedervi." L'Agricoltura Italiana 19: 132-37.

Conklin, Harold C.

1955 "Hanunóo Color Categories." Southwestern Journal of Anthropology Research 11, no. 4: 339-44. https://doi.org/10.1086/soutjanth.11.4.3628909.

1957 "Hanunóo Agriculture: A Report on an Integral System of Shifting Cultivation in the Philippines." Rome: Food and Agriculture Organization.

Cosgrove, Denis

1985 "Prospect, Perspective, and the Evolution of the Landscape Idea." Transactions of the Institute of British Geographers 10, no. 1: 45-62. https://doi.org/10.2307/ 622249.

Crutzen, Paul J., and Eugene F. Stoermer

2000 “The 'Anthropocene." Global Change Newsletter, no. 41: 17-18.

de la Cadena, Marisol

2010 "Indigenous Cosmopolitics in the Andes: Conceptual Reflections beyond 'Politics.” Cultural Anthropology 25, no. 2: 334-70. https://doi.org/10.1111/

Dove, Michael R. j.1548-1360.2010.01061.x.

1983 "Theories of Swidden Agriculture and the Political Economy of Ignorance." Agroforestry Systems 1, no. 2: 85-99. https://doi.org/10.1007/BF00596351.

Edwards, Paul N.

2010 A Vast Machine: Computer Models, Climate Data, and the Politics of Global Warming. Cambridge, Mass.: MIT Press.

Evans-Pritchard, E. E.

1940 The Nuer: A Description of the Modes of Livelihood and Political Institutions of a Nilotic People. New York: Oxford University Press.

Gan, Elaine

2017 “An Unintended Race: Miracle Rice and the Green Revolution.” Environmental Philosophy 14, no. 1: 61-81. https://doi.org/10.5840/envirophil20174648.

Giannini, Raffaello, and Antonio Gabbrielli

2013 "Evolution of Multifunctional Land-use Systems in Mountain Areas in Italy." Italian Journal of Forest and Mountain Environments 68, no. 5: 259-68. https://

Gibelli, Giuseppe doi.org/10.4081/ija.2013.e16.

1883 Nuovi studi sulla malattia del castagno, detta dell'inchiostro. Bologna, Italy: Gamberini e Parmeggiani.

Gimmi, Urs, Benjamin Poulter, Annett Wolf, Hanspeter Portner, Pascale Weber, and Matthias Bürgi

2013 "Soil Carbon Pools in Swiss Forests Show Legacy Effects from Historic Forest Litter Raking." Landscape Ecology 28, no. 5: 835-46. https://doi.org/10.1007/ s10980-012-9778-4.

Grove, A. T., and Oliver Rackham

2001 The Nature of Mediterranean Europe: An Ecological History. New Haven, Conn.: Yale University Press.

Haraway, Donna J.

2016 Staying With the Trouble: Making Kin in the Chthulucene. Durham, N.C.: Duke University Press. 
Hulme, Mike

2012 "What Sorts of Knowledge for What Sort of Politics? Science, Climate Change, and the Challenges of Democracy." Science, Society, and Sustainability (3S) Working Paper 2012-15. Norwich, UK: University of East Anglia. https:// 3sresearch.org/2014/12/04/3s-wp-2012-15-hulme-what-sorts-of-knowledgefor-what-sort-of-politics-science-climate-change-and-the-challenges-ofdemocracy.

Hustak, Carla, and Natasha Myers

2012 "Involutionary Momentum: Affective Ecologies and the Sciences of Plant/Insect Encounters." differences 23, no. 3: 74-118. https://doi.org/10.1215/104073911892907.

Ingold, Tim

2011 “Materials Against Materiality." In Being Alive: Essays on Movement, Knowledge, and Description, 19-32. New York: Routledge.

2012 "Toward an Ecology of Materials." Annual Review of Anthropology 41: 427-42. https://doi.org/10.1146/annurev-anthro-081309-145920.

Larkin, Brian

2013 “The Politics and Poetics of Infrastructure." Annual Review of Anthropology 42: 327-43. https://doi.org/10.1146/annurev-anthro-092412-155522.

Latour, Bruno

1988 The Pasteurization of France. Translated by Alan Sheridan and John Law.

Law, John Cambridge, Mass.: Harvard University Press. Originally published in 1984.

2015 “What's Wrong with a One-World World?” Distinktion 16, no. 1: 126-39. https://doi.org/10.1080/1600910X.2015.1020066.

Law, John, and Marianne Elisabeth Lien

2013 "Slippery: Field Notes on Empirical Ontology." Social Studies of Science 43, no. 3: 363-78. https://doi.org/10.1177/0306312712456947.

Lévi-Strauss, Claude

1955 Tristes tropiques. Paris: Plon.

Lien, Marianne Elisabeth, and John Law

2011 “'Emergent Aliens': On Salmon, Nature, and Their Enactment.” Ethnos 76, no. 1: 65-87. https://doi.org/10.1080/00141844.2010.549946.

Massoni, Giovanni

1999 La pieve e la communita di Vorno. Lucca, Italy: Maria Pacini Fazzi.

Mathews, Andrew S.

2005 "Power/Knowledge, Power/Ignorance: Forest Fires and the State in Mexico." Human Ecology 33, no. 6: 795-820. https://doi.org/10.1007/s10745-0058211-x.

Mazzarosa, Antonio

1846 Le pratiche della campagna Lucchese. Lucca, Italy: Tipografia di Giuseppe Giusti.

Mol, Annemarie

2002 The Body Multiple: Ontology in Medical Practice. Durham, N.C.: Duke University Press.

Moore, Jason W.

2015 Capitalism in the Web of Life: Ecology and the Accumulation of Capital. New York: Verso.

Nazarea, Virginia D.

2006 "Local Knowledge and Memory in Biodiversity Conservation." Annual Review of Anthropology 35: 317-35. https://doi.org/10.1146/annurev.anthro.35.081705. 123252.

Olwig, Kenneth R.

1996 "Recovering the Substantive Nature of Landscape." Annals of the Association of American Geographers 86, no. 4: 630-53. https://doi.org/10.1111/j.14678306.1996.tb01770.x. 
Pedreschi, Luigi

1963 I terrazzamenti agrari in Val di Serchio. Pisa, Italy: Libreria Goliardica.

Puccinelli, Giuliana

2010 "All'origine di una monocultura: L'espansione del castagneto nella Valle del Serchio in Età Moderna.” Rivista di storia dell'agricoltura 50, no. 1: 3-68. http:// rsa.storiaagricoltura.it/scheda. asp?IDF=131\&IDS=3\&IDP=1.

Rizzo, Davide, Fabio Casella, Mariassunta Galli, and Enrico Bonani

2009 "La gestione delle sistemazioni idraulico-agrarie nel Monte Pisano: schede descrittive e operative.” Land Lab, Scuola Superiore di Sant'Anna Pisa, Comune

Rocheleau, Dianne di Calci, Italy.

1995 "Maps, Numbers, Text, and Context: Mixing Methods in Feminist Political Ecology." Professional Geographer 47, no. 4: 458-66. https://doi.org/10.1111/

Star, Susan Leigh j.0033-0124.1995.00458.x.

1999 “The Ethnography of Infrastructure.” American Behavioral Scientist 43, no. 3: 377-

Stewart, Kathleen 91. https://doi.org/10.1177/00027649921955326.

2017 "In the World that Affect Proposed." Cultural Anthropology 32, no. 2: 192-98.

Squatriti, Paolo https://doi.org/10.14506/ca32.2.03.

2013 Landscape and Change in Early Medieval Italy: Chestnuts, Economy, and Culture. New York: Cambridge University Press.

Swanson, Heather Ann

2017 "Placing a Golden Spike at the Golden Spike: Railroads in the Making of the Anthropocene." In Placing the Golden Spike: Landscapes of the Anthropocene, edited by Dehlia Hannah, 102-111. Milwaukee, Wis.: Institute of Visual Arts, University of Wisconsin-Milwaukee.

Swanson, Heather, Nils Bubandt, and Anna Tsing

2015 "Less than One but More than Many: Anthropocene as Science Fiction and Scholarship-in-the-Making." Environment and Society 6, no. 1: 149-66. https:// doi.org/10.3167/ares.2015.060109.

Tsing, Anna Lowenhaupt

2015 The Mushroom at the End of the World: On the Possibility of Life in Capitalist Ruins. Princeton, N.J.: Princeton University Press. 